\title{
Pemahaman dan Partisipasi Guru Sekolah Dasar Dalam Menulis Karya Ilmiah
}

\author{
Maulina Hendrik ${ }^{1}$, Vika Martahayu ${ }^{2}$ \\ STKIP Muhammadiyah Bangka Belitung \\ maulina.hendrik@stkipmbb.ac.id ${ }^{1}$, vika.martahayu@stkipmbb.ac.id ${ }^{2}$
}

\begin{abstract}
The general objective of the study is to identify the understanding and participation of teacher in academic writing. The specific objectives of the study are to (i) identify the understanding of elementary school teacher in academic writing in Rangkui District; (ii) to identify the participation of elementary school teacher in academic writing in Rangkui District; and (iii) to examine factors that affect the elementary school teacher in academic writing in Rangkui District. The study employed the qualitative approach with source of data as follows: (i) 50 elementary school teachers as the primary data; and (ii) documentation derived from some literatures and other reading sources as the secondary data. The data was gained by using the interview and documentation. Furthermore, it was analyzed by using data analysis technique i.e. data reduction, data presentation, decision making. The results showed: (i) $28 \%$ of respondents considered as having understanding, $35 \%$ of them considered as lack of understanding, and $37 \%$ considered as not having understanding at all in academic writing. (ii) in terms of the participation level of elementary school teacher, $20 \%$ of respondents stated often, $35 \%$ of them stated rarely, and $45 \%$ of them stated not having the academic writing. (iii) Factors that affect teacher in participating on having the academic writing were lack of time, motivation, knowledge and idea.
\end{abstract}

Keywords : Academic Writing, Teacher Participation and Understanding

\section{ABSTRAK}

Penelitian ini secara umum bertujuan untuk mengetahui pemahaman dan partisipasi guru dalam menulis karya ilmiah. Tujuan khusus penelitian ini adalah untuk mengetahui: (1) Pemahaman guru SD se-Kecamatan Rangkui dalam menulis karya ilmiah; (2) Partisipasi guru SD se-Kecamatan Rangkui dalam menulis karya ilmiah; (3) Faktorfaktor yang mempengaruhi guru SD se-Kecamatan Rangkui dalam menulis karya ilmiah. Penelitian ini menggunakan pendekatan kualitatif dengan sumber data penelitian yang terdiri dari: (1) Sumber data primer, yakni guru SD se-Kecamatan Rangkui sebanyak 50 orang; (2) Sumber data sekunder, yakni data yang diperoleh dari studi dokumentasi yang diperoleh dari berbagai literatur dan sumber bacaan lainnya. Data penelitian dikumpulkan dengan teknik wawancara dan dokumentasi, kemudian dianalisis dengan menggunakan teknik analisis data berupa reduksi data, penyajian data, dan pengambilan keputusan. Hasil penelitian diperoleh: (1) Tingkat pemahaman para guru SD se-Kecamatan Rangkui Kota Pangkalpinang dalam menulis karya ilmiah sebanyak 28\% dikategorikan paham, 35\% kurang paham, dan 37\% tidak paham; (2) Tingkat partisipasi guru dalam menulis karya ilmiah sebanyak 20\% responden menyatakan sering, 35\% responden menyatakan jarang, dan $45 \%$ responden menyatakan informan belum menulis karya ilmiah; serta (3) Faktor yang menghambat partisipasi guru dalam menulis karya ilmiah adalah keterbatasan waktu, motivasi, kurangnya pengetahuan tentang kompetensi profesional, serta keterbatasan mengembangkan ide.

Kata Kunci : Menulis Karya Ilmiah, Partisipasi Guru, dan Pemahaman. 


\section{PENDAHULUAN}

"Guru mulia karena karyanya". Tutur Anis Baswedan saat memberikan sambutan di peringatan Hari Guru Nasional Tahun 2016. Ungkapan ini berarti "jika ingin dihargai maka guru harus berkarya". Berkarya akan menghasilkan sesuatu, menghasilkan karya-karya inovatif dalam meningkatkan kualitas pembelajaran dan yang paling utama adalah kiprahnya dalam mencerdaskan anak-anak bangsa sehingga melahirkan generasi penerus yang berilmu, terampil, dan berbudi pekerti luhur.

Tantangan dan tuntutan perubahan yang terjadi dalam perkembangan dunia pendidikan mutakhir menuntut penyesuaian (adjustment) pada banyak aspek penyelenggaraan pendidikan. Para Guru sebagai ujung tombak utama peran pengajaran dan pendidikan di sekolah pun tak ayal dituntut untuk mampu menyelaraskan diri dengan arah dan dinamika perubahan tersebut. Pemuliaan Guru sangat tergantung pada seberapa mampu ia mengembangkan dan meningkatkan kompetensi profesi pendidik. Kecanggihan teknologi, metodologi dan pesatnya perkembangan ilmu pengetahuan membuat guru ditantang untuk juga mampu berkontribusi signifikan guna mengatasi pelik dan kompleksnya persoalan pendidikan di Indonesia.

Di Provinsi Kepulauan Bangka Belitung, guru mempunyai bagian yang utuh dari tantangan perubahan pendidikan. Sejak reformasi pendidikan di Indonesia terus didiseminasikan, perubahan besar di Indonesia, tak luput berimbas pada dinamika pembangunan pendidikan di Provinsi muda ini. Kebutuhan upgrading dan pengembangan guru yang lebih professional menjadikan diskursus pengembangan kompetensi guru menjadi mutlak pula berlangsung di negeri Serumpun Sebalai. Ditambah dengan kondisi timpangnya kompetensi guru di Indonesia, upaya ini hendaknya diliputi semangat akselerasi.

Permendiknas Nomor 16 Tahun 2007 tentang Standar Kualifikasi Akademik dan Kompetensi Guru menyatakan bahwa guru memiliki empat kompetensi utama yang terintegrasi dalam kinerja guru, yakni: kompetensi kepribadian, sosial, pedagogik, dan profesional. Kompetensi kepribadian merupakan kemampuan personal seorang guru yang mencerminkan kepribadian yang mantap, stabil, dewasa, arif dan berwibawa, menjadi teladan bagi peserta didik, dan berakhlak mulia. Kompetensi sosial menitik beratkan pada kemampuan guru untuk berkomunikasi dan bergaul secara efektif dengan peserta didik, tenaga kependidikan, orang tua/wali peserta didik, dan masyarakat sekitar.

Kompetensi pedagogik ialah kemampuan pemahaman terhadap peserta didik, perancangan dan pelaksanaan pembelajaran, evaluasi hasil belajar, dan 
pengembangan peserta didik untuk mengaktualisasikan berbagai potensi yang dimilikinya. Kompetensi Profesional adalah penguasaan materi pembelajaran secara luas dan mendalam, yang mencakup penguasaan materi kurikulum mata pelajaran di sekolah dan substansi keilmuan yang menaungi materinya, serta penguasaan terhadap struktur dan metodologi keilmuannya. Kompetensi-kompetensi tersebut haruslah menjadi kesatuan yang itu agar dapat menciptakan guru yang berkualitas.

Dalam bidang kompetensi professional, kompetensi yang harus dimiliki guru ialah ihwal menulis. Banyak alasan mengapa guru harus menulis misalnya guru dapat menuangkan ide-ide kreatifnya dari apa yang dituliskannya, guru akan mampu mengkomunikasikan dari apa yang ada dalam alam pikirannya, sekaligus melakukan refleksi diri dari apa yang telah dilakukannya. Selain itu, menulis juga membuat guru menjadi kritis dari kebijakankebijakan pendidikan yang terkadang kurang bersahabat dengan pahlawan insan cendekia ini.

Kewajiban seorang guru dalam memublikasi karya ilmiah tercantum dalam Peraturan Menteri Negara Pendayagunaan Aparatur Negera dan Reformasi Birokrasi (Permen PANRB) Nomor 16 Tahun 2009 tentang Jabatan Fungsional Guru dan Angka Kreditnya. Pasal 11 dalam peraturan tersebut menyatakan bahwa salah satu kegiatan pengembangan keprofesian berkelanjutan guru adalah publikasi ilmiah. Jenis publikasi ilmiah di antaranya: hasil penelitian, gagasan inovatif, tulisan ilmiah populer, dan artikel ilmiah dalam bidang pendidikan; publikasi buku teks pelajaran, buku pengayaan, dan pedoman Guru.

Berdasarkan kedua landasan utama di atas, dapat dimaknai bahwa kewajiban memublikasi ilmiah akan menambah pengetahuan guru untuk mengajar lebih efektif dan efisien. Selain itu, melalui publikasi tersebut guru dapat mengkritisi berbagai permasalahan pendidikan yang terjadi saat ini dan akan datang serta dapat pula mengkritisi kegiatan pembelajaran guna menciptakan pembelajaran yang inovatif.

Secara umum, dengan menggunakan asumsi dan indikator sederhana, kondisi produktivitas publikasi karya ilmiah guru sebagai salah satu bidang kompetensi professional guru, terutama di tataran pendidikan dasar, relatif rendah. Ada banyak faktor dan kendala yang menginisiasi problematika peningkatan kompetensi literasi ini. Persoalan utama disematkan pada kultur menulis karya ilmiah yang belum terbangun, rekayasa regulasi yang tak imbang dengan beban kerja pendidik, terlebih motivasi berkarya serta concern pelatihan dan pembinaan yang belum terstruktur hingga capaian output yang tuntas, menjadi beberapa permasalahan yang layak dijadikan bahan pertimbangan ketika 
mengambil kebijakan pengelolaan dan pemantauan yang efektif dalam kajian pengembangan dan peningkatan mutu kompetensi professional Guru.

Kewajiban mempublikasikan karya ilmiah akan menambah pengetahuan guru untuk mengajar lebih efektif dan efisien. Selain itu, melalui publikasi tersebut diharapkan guru dapat mengkritisi dan membangun solusi bagi berbagai permasalahan pendidikan yang terjadi saat ini dan akan datang serta dapat pula mengkritisi kegiatan pembelajaran guna menciptakan pembelajaran yang inovatif. Sosok guru menurut Undang-Undang Republik Indonesia Nomor 14 tahun 2005 tentang Guru dan Dosen ialah pendidik profesional dengan tugas utama mendidik, mengajar, membimbing, mengarahkan, melatih, menilai, dan meng-evaluasi peserta didik pada pendidikan anak usia dini jalur pendidikan formal, pendidikan dasar, dan pendidikan menengah. Di era reformasi, kesejahteraan guru menjadi salah satu perhatian utama pemerintah. Selama ini pangkat guru tinggi karena kenaikan otomatis dan cepat, namun kesejahteraan rendah.

Berdasarkan permasalahan di atas, maka penelitian ini bertujuan untuk mengetahui: 1) Tingkat pemahaman guru SD di Wilayah Kecamatan Rangkui, Kota Pangkalpinang dalam menulis karya ilmiah? 2) Tingkat partisipasi guru SD di Wilayah Kecamatan
Rangkui, Kota Pangkalpinang dalam menulis karya ilmiah? 3) Faktor-faktor yang memengaruhi tingkat partisipasi guru SD di Wilayah Kecamatan Rangkui, Kota Pangkalpinang dalam menulis karya ilmiah.

Pemahaman berasal dari kata paham yang mempunyai arti "mengerti benar", sedangkan pemahaman merupakan proses pembuatan cara memahami (Fajri \& Senja, 2008: 607-608). Menurut Sudjana (2016: 24), "pemahaman adalah hasil belajar, misalnya peserta didik dapat menjelaskan dengan susunan kalimatnya sendiri atas apa yang dibacanya atau didengarnya, memberi contoh lain dari yang telah dicontohkan guru dan menggunakan petunjuk penerapan pada kasus lain". Jadi, dapat disimpulkan bahwa seseorang dikatakan memahami sesuatu apabila ia dapat memberikan penjelasan atau memberi uraian yang lebih rinci tentang hal yang dia pelajari dengan menggunakan bahasanya sendiri. Lebih baik lagi apabila dapat memberikan contoh atau menyinergikan sesuatu yang dia pelajari dengan permasalahan-permasalahan yang ada di sekitarnya.

Menurut Daryanto (2008: 106) kemampuan pemahaman berdasarkan tingkat kepekaan dan derajat penyerapan materi dapat dijabarkan ke dalam tiga tingkatan, yaitu: menerjemahkan (translation), menafsirkan (interpretation), mengekstrapolasi (extrapolation). 
Banyak ahli memberikan pengertian mengenai konsep partisipasi. Menurut Pidarta dalam Astuti (2009: 31-32), "partisipasi adalah pelibatan seseorang atau beberapa orang dalam suatu kegiatan. Keterlibatan dapat berupa keterlibatan mental dan emosi serta fisik dalam menggunakan segala kemampuan yang dimilikinya (berinisiatif) dalam segala kegiatan yang dilaksanakan serta mendukung pencapaian tujuan dan tanggungjawab atas segala keterlibatan”.

Karya tulis ilmiah yang harus ditulis oleh guru untuk mengembangkan diri dan harus dipublikasikan kepada masyarakat sebagai bentuk kontribusi guru terhadap peningkatan kualitas proses pembelajaran di sekolah dan pengembangan dunia pendidikan secara umum dan untuk memperoleh angka kredit sesuai dengan Peraturan Menteri Negara Pendayagunaan Aparatur Negara dan Reformasi Birokrasi Nomor 16 Tahun 2009 tentang Jabatan Fungsional Guru dan Angka Kreditnya adalah publikasi ilmiah.

Pada penelitian yang dilakukan, jenis karya ilmiah yang menjadi objek kajian adalah makalah berupa hasil penelitian atau kajian pustaka yang ditulis menjadi artikel ilmiah.

\section{METODE PENELITIAN}

Penelitian ini dilakukan di wilayah Pangkalpinang khususnya di Sekolah Dasar
se-Kecamatan Rangkui, Kota Pangkalpinang, Provinsi Kepulauan Bangka Belitung. Sumber data penelitian ini terbagi 2, yaitu (1) sumber data primer meliputi kepala sekolah dan guru Sekolah Dasar di wilayah Kecamatan Rangkui, Pangkalpinang sebanyak 50 orang., (2) sumber data sekunder. Sumber data sekunder adalah data yang diperoleh dari studi dokumentasi yang diperoleh dari literatur-literatur, dan sumber bacaan lainnya, misalnya artikel, data dari internet, serta hasil seminar yang berkaitan dengan tema penelitian.

Teknik pengumpulan data merupakan bagian terpenting dalam sebuah penelitian. Dalam penelitian ini, teknik pengumpulan data berupa wawancara dan dokumentasi. Berdasarkan teknik tersebut, maka instrumen yang digunakan adalah pedoman wawancara dan rekaman data. Data yang terkumpul kemudian dianalisis secara deskriptif dengan menggunakan teknik data reduction, data display, dan conclusion drawing/verification.

Reduksi data yaitu suatu proses pemilahan, pemusatan perhatian pada penyederhanaan, pengabstrakan dan transformasi data kasar yang muncul dari catatan-catatan tertulis di lapangan. Reduksi data yang berupa transkrip hasil wawancara terhadap subjek penelitian.

Setelah data direduksi, data disusun sedemikian rupa sehingga memberikan kemungkinan adanya penarikan kesimpulan 
dan pengambilan tindakan. Adapun bentuk yang lazim digunakan pada data kualitatif adalah dalam bentuk teks naratif yang terdapat pada BAB IV Hasil Penelitian dan Pembahasan.

Dalam penelitian ini disajikan mengenai makna dari data yang dikumpulkan. Dari data tersebut akan diperoleh kesimpulan yang tentatif, kabur, kaku dan meragukan, sehingga kesimpulan tersebut perlu diverifikasi. Verifikasi dilakukan dengan melihat kembali reduksi data maupun display data sehingga simpulan yang diambil tidak menyimpang.

\section{III.HASIL PENELITIAN DAN PEMBAHASAN}

\section{A. Pemahaman Guru SD Wilayah Kecamatan Rangkui, Kota Pangkalpinang dalam Menulis Karya Ilmiah}

Karya ilmiah merupakan hasil pemikiran seseorang terhadap suatu gejala atau potensi yang dapat mengembangkan ilmu pengetahuan dan teknologi. Karya ilmiah dihasilkan dari kegiatan ilmiah melalui kepustakaan, kumpulan pengalaman, penelitian, dan pengetahuan orang lain sebelumnya. Pemahaman para guru SD seKecamatan Rangkui Kota Pangkalpinang dalam menulis karya ilmiah sebanyak $28 \%$ dikategorikan paham, 35\% kurang paham, dan $37 \%$ tidak paham. Persentase tersebut dapat dilihat dalam diagram lingkaran berikut.

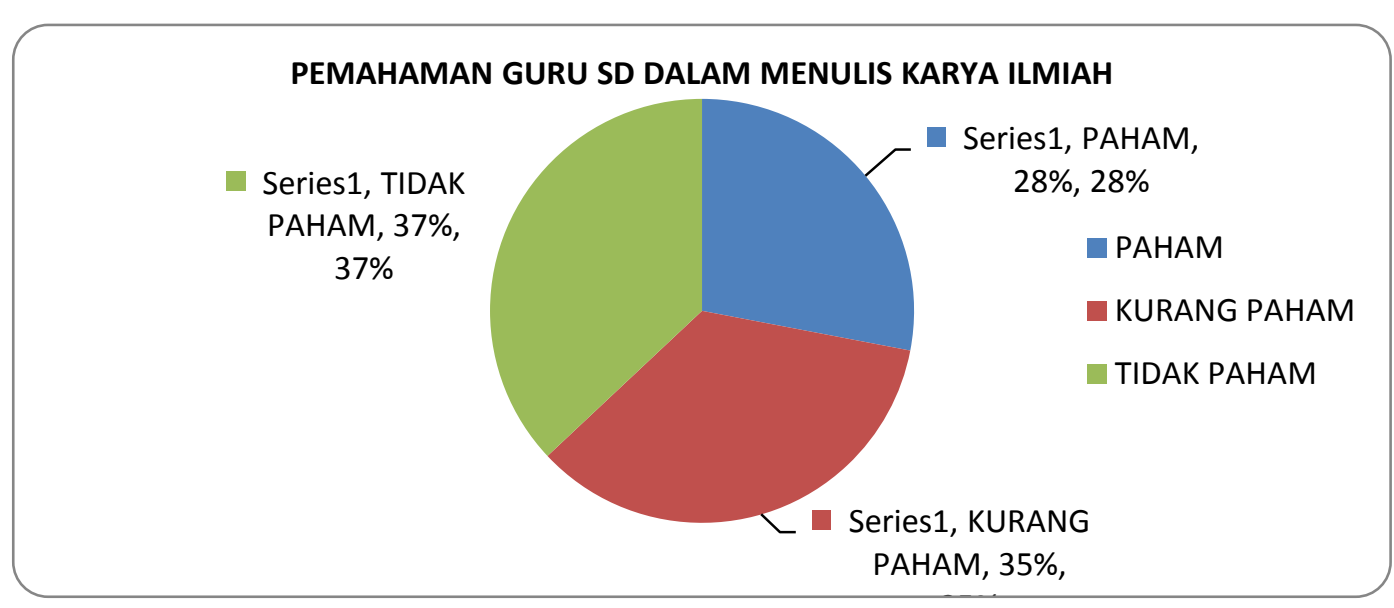

Gambar 1

Diagram Lingkaran Tingkat Pemahaman Guru SD dalam Menulis Karya Ilmiah

Berdasarkan data pemahaman di atas dapat dijelaskan bahwa pemahaman guru tersebut terhadap karya ilmiah masih perlu ditingkatkan. Pada umumnya guru sekedar mengetahui bahwa karya tulis wajib dibuat agar mendapat angka kredit sebagai syarat untuk kenaikan pangkat dan golongan. Gambaran ini merupakan indikasi bahwa guru kurang mengetahui kebijakan baru mengenai PKB (Peningkatan Keprofesian 
Berkelanjutan). Pada hal dalam proses pendidikan dan pembelajaran, kemampuan guru dalam menulis sangat dibutuhkan sebagai wahana untuk menyampaikan materi. Guru dapat menyampaikan banyak hal dalam bentuk tulisan sehingga anak didik dapat belajar secara mandiri. Menulis karya tulis ilmiah merupakan sarana bagi guru untuk menuliskan gagasan yang ada dalam pikirannya, tulisan yang dihasilkan merupakan wujud intelektual diri. Menurut Saroni (2012: 25) semakin banyak karya tulis yang dihasilkan semakin bagus isi tulisan dan hal tersebut menunjukkan semakin tinggi tingkat intelektual seorang guru.

B. Partisipasi Guru SD Wilayah Kecamatan Rangkui, Kota Pangkalpinang dalam Menulis Karya

\section{Ilmiah}

Pemahaman guru mengenai pengertian karya ilmiah, sistematika penulisan, langkah-langkah penulisan, dan intensitas dalam menulis karya ilmiah menjadi faktor kunci penulisan karya ilmiah. Sebanyak $20 \%$ responden menyatakan sering menulis karya ilmiah dan dipublikasikan, 35\% responden menyatakan jarang menulis dan memublikasikan, sedangkan $45 \%$ responden menyatakan informan belum atau tidak pernah menulis karya ilmiah. Responden pernah menulis karya ilmiah sebagai syarat kenaikan pangkat. Kegiatan seminar dan workshop yang sering diikuti guru adalah pengembangan pembelajaran yang inovatif dan PTK. Dalam kegiatan ini para guru biasanya hanya menjadi peserta pasif dan tidak berdampak bagi peningkatan pemahaman serta pengetahuan guru. Gambaran persentase partisipasi para guru dalam menulis karya ilmiah dapat dilihat pada diagram berikut. 


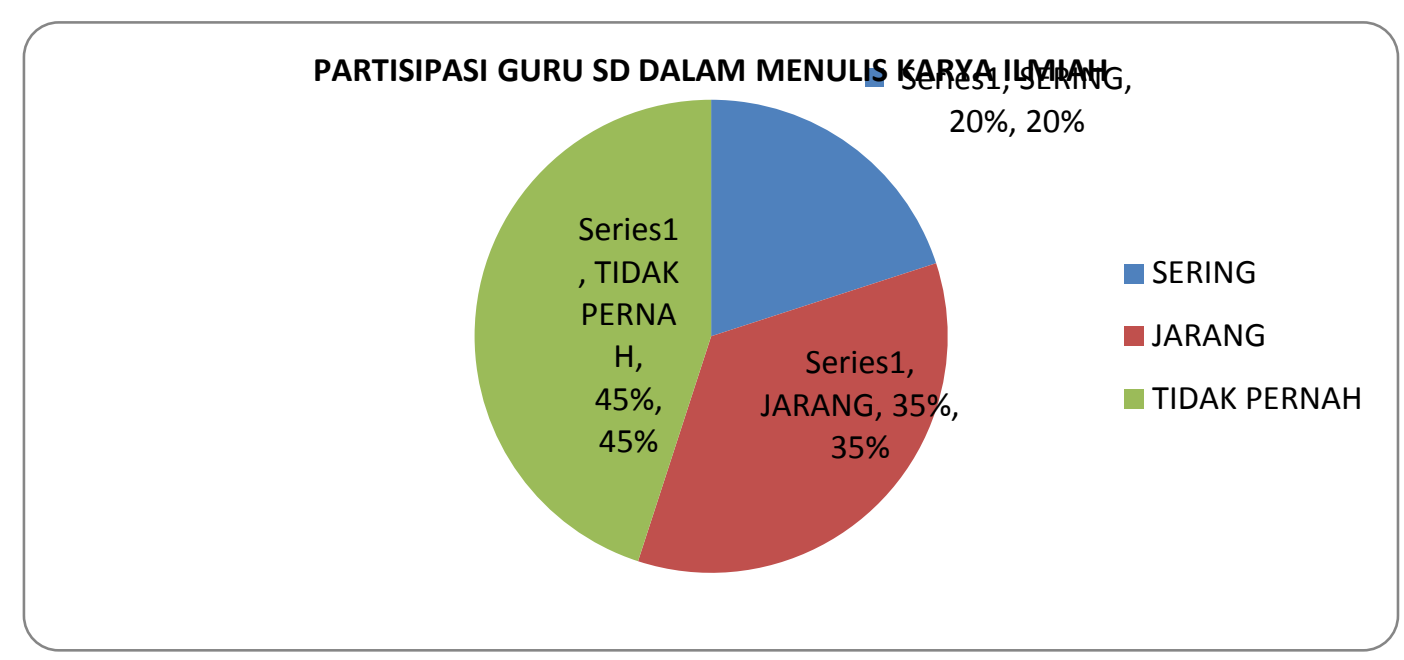

Gambar 2

\section{Diagram Lingkaran Tingkat Partisipasi Guru SD dalam Menulis Karya Ilmiah}

Secara keseluruhan partisipasi guru di wilayah Kecamatan Rangkui Kota Pangkalpinang dalam menulis karya ilmiah dikategorikan cukup. Hal tersebut dapat terlihat saat diwawancarai "pernahkah dan seberapa banyak menulis karya ilmiah?" hampir keseluruhan menjawab belum pernah. Ungkapan tersebut sesuai dengan hasil penelitian dari Ariffianto dan Liana (2015:396), bahwa guru profesional harus memiliki berbagai kemampuan, salah satu kemampuannya adalah menulis karya tulis ilmiah. Dengan menulis karya ilmiah, selain mendapat kenaikan pangkat, jabatan dan golongan, akan dijadikan tolak ukur keberhasilannya serta untuk menunjukkan keprofesionalannya.

C. Faktor-Faktor Penghambat yang Mempengaruhi Partisipasi Guru SD di Wilayah Kecamatan Rangkui, Kota Pangkalpinang dalam Menulis Karya Ilmiah
Berdasarkan hasil wawancara yang dilakukan, setiap guru memiliki hambatan atau kendala dalam menulis karya ilmiah. Pertama, hambatan yang dirasakan para guru, di antaranya:

\section{Keterbatasan Waktu}

Faktor utama sulitnya para guru berpartisipasi dalam menulis karya ilmiah adalah terbatasnya waktu. Kondisi guru SD se-Kecamatan Rangkui merasakan bahwa terbatasnya waktu dikarenakan tuntutan administrasi pembelajaran dan beban mengajar yang padat.

Selain itu, sulitnya membagi waktu antara pekerjaan di sekolah dengan pekerjaan di rumah. Tuntutan pekerjaan di sekolah, pembelajaran dilaksanakan secara penuh (fullday) dari pagi hingga sore. Waktu yang tersedia saat pulang hanya beberapa jam saja dan dipergunakan untuk istirahat. Waktu 
menjadi penghambat guru dalam mengembangkan diri. Tidak ada satu pun guru yang diwawancarai mengembangkan diri secara mandiri di luar jam mengajar.

\section{Motivasi}

Motivasi merupakan salah satu faktor penghambat internal seperti sikap para guru belum memiliki kebiasaan membaca buku, belum memiliki kemampuan berbahasa dengan baik dan belum adanya motivasi untuk menulis. Faktor-faktor internal ini terungkap dari pernyataan beberapa informan sebagai berikut.

"Kami belum memahami konsep karya ilmiah. Konsep penulisan, metode yang benar seperti apa kami belum memahami dengan baik. Keadaan yang kami alami, kurangnya bimbingan pembuatan PTK, tidak ada bimbingan cara penulisan yang diadakan pemerintah secara gratis". (informan N18)

"Kesulitan dalam membuat PTK secara umum ada pada pengembangan konsep penelitiannya. Mulai dari menentukan judul yang pas, rumusan masalah, dan teori yang digunakan. Lantas metodenya bagaimana itu juga jadi hambatan. Seandainya tidak ada yang membimbing, pasti saya kesulitan. (informan N20)

"Secara prinsip kami belum memahami konsep karya ilmiah, ilmu dalam membuat PTK masih sedikit, cara pembuatan belum paham dan jelas, pendidikan dan latihan PTK belum pernah mengikuti. Ilmu dalam pembuatan artikel ilmiah belum memadai, cara pembuatan belum ada bayangan, pendidikan dan latihan belum pernah mengikuti” (informan N10).

"Sebagai guru swasta tidak ada ruang untuk membuat penelitian atau karya ilmiah, seandainya membuat karya hanya digunakan untuk pribadi, tidak ada kenaikan pangkat seperti guru PNS. Saya membuat karya ilmiah saat PLPG. belum pernah membuat artikel ilmiah dan tidak ada motivasi dalam membuat artikel ilmiah" (informan N35).

Selain itu, rendahnya motivasi guru dalam menulis karya ilmiah dikarenakan faktor usia dan belum adanya pihak terkait yang memberikan pelatihan pada guru terkait penulisan karya ilmiah. Pelatihan yang dilaksanakan selama ini sulit diikuti para guru. Kendalanya adalah dilakukan saat jam mengajar. Harus meninggalkan jam mengajar minimal 3-4 hari. Selain itu, terbatasnya kuota peserta (tanpa dipungut biaya) dan biaya mahal (jika berkontribusi).

Hal tersebut sesuai dengan pendapat Marijan (2011:46) bahwa faktor penghambat kegiatan menulis ada dua, yaitu faktor internal dan faktor eksternal. Dan faktor usia merupakan hambatan yang berasal dari dalam diri guru atau faktor internal. Sedangkan faktor belum adanya pelatihan dari pihak sekolah merupakan faktor yang berasal dari luar guru atau disebut juga faktor eksternal.

Motivasi merupakan salah satu faktor yang bisa menggerakkan hati 
seseorang untuk bisa melakukan suatu pekerjaan. Motivasi diartikan sebagai kekuatan seseorang sehingga muncul antusiasme dalam melakukan sesuatu baik yang bersumber dari dalam diri individu itu sendiri maupun dari luar individu.

3. Kurangnya Pengetahuan Tentang Kompetensi Professional

Keterbatasan guru dalam memahami pengertian kompetensi profesional mengakibatkan para guru menjadi salah persepsi. Menurut Marijan (2011: 44) apabila salah persepsi terjadi pada guru berkaitan dengan kurangnya pengetahuan mengenai karya tulis ilmiah, guru menganggap bahwa menulis merupakan hal yang sulit untuk dilakukan, paradigma tersebut juga memunculkan keengganan guru dalam menulis karya ilmiah karena merasa hal tersebut tidak berguna untuk mereka. Padahal sesungguhnya dengan menulis karya ilmiah seorang guru dapat meningkatkan kualitas pembelajaran yang berkaitan dengan kompetensi profesional. Peningkatan kompetensi profesional tidak hanya untuk guru yang sudah PNS akan tetapi juga untuk para guru swasta.

Pada dasarnya segala bentuk pengembangan diri sudah dilakukan oleh para guru meski hasilnya belum maksimal. Guru telah berusaha melakukan pengembangan diri untuk memenuhi dan meningkatkan kompetensi paedagogik, profesional, sosial, dan kepribadian. Wawancara dengan informan N17, diperoleh gambaran bahwa "Selama ini sebagian besar guru telah banyak membaca buku, mengikuti workshop, dan outbond. Jika itu diikuti, saya rasa cukup untuk meningkatkan kompetensi”. Kemudian, informan N8 mengatakan bahwa selain membaca buku, juga sering melihat di internet. Karena lebih mudah jika mencari di internet. Datang di seminar atau workshop juga pernah. Itu bisa mendukung kompetensi saya sebagai guru".

Informasi yang didapatkan dari kedua nara sumber di atas tidak berbeda dengan yang dilakukan oleh informan N18, "Pengembangan kompetensi yang telah dilakukan dengan mendatangi seminar, workshop, dan kegiatan Musyawarah Guru Mata Pelajaran (MGMP)".

4. Keterbatasan Mengembangkan Ide

Faktor penghambat penulisan karya ilmiah yang keempat adalah terbatasnya para guru mengembangkan ide dalam menulis karya ilmiah. Hambatan penulisan karya ilmiah yang keempat ini sesuai dengan pendapat Budiharso (2009: 59), bahwa masalah empiris yang dihadapi guru salah satunya adalah 
keterbatasan penulis dalam mengembangkan ide atau gagasan yang dimiliki. Munculnya hambatan tersebut dikarenakan tidak adanya bimbingan dan sumber referensi yang terbatas. Selain itu, pemahaman dalam mencari referensi, cara mengoperasikan komputer juga menjadi hambatan dalam mengembangkan ide.

Gambaran pemahaman guru-guru pada karya ilmiah di atas sejalan dengan hasil penelitian Sumardjoko (2017: 191198), bahwa kendala guru untuk menulis karya tulis ilmiah adalah sebagai berikut. (1) Minat membaca para guru tergolong rendah. Faktor rendahnya minat membaca menutup wawasan, pengertian, pemahaman, semangat, dan motivasi dalam memandang suatu permasalahan yang dapat diangkat sebagai bahan dalam penulisan karya tulis ilmiah. (2) Guru kurang informasi mengenai kegiatan pengembangan terbaru. Guru mendapat informasi setengah-setengah sehingga lebih mempercayai isu yang berkembang. Salah satu isu yang beredar ialah isu mengenai pembuatan karya tulis ilmiah yang sangat berat namun tidak dinilai dengan layak. (3) Salah persepsi, guru yang kurang informasi terhadap karya tulis ilmiah menjadikan salah persepsi mengenai menulis karya tulis ilmiah. Guru menganggap menulis merupakan hal yang sulit untuk dilakukan. Paradigma tersebut memunculkan keengganan guru untuk menulis karena merasa hal tersebut tidak berguna. Guru menganggap peraturan yang ditetapkan oleh pemerintah tidak berakibat langsung pada profesinya sehingga para guru tidak melaksanakan kewajiban menulis karya tulis ilmiah dengan sungguh-sungguh.

\section{KESIMPULAN}

Berdasarkan hasil penelitian dan pembahasan tersebut, dapat disimpulkan beberapa hal terkait pemahaman, partisipasi, dan faktor-faktor yang mempengaruhi partisipasi guru dalam menulis karya ilmiah. Pertama, berdasarkan hasil wawancara diperoleh gambaran bahwa pemahaman para guru SD se-Kecamatan Rangkui Kota Pangkalpinang dalam menulis karya ilmiah sebanyak 28\% dikategorikan paham, 35\% kurang paham, dan 37\% tidak paham.

Kedua, Sebanyak 20\% responden menyatakan sering menulis karya ilmiah dan dipublikasikan, 35\% responden menyatakan jarang menulis dan memublikasikan, sedangkan $45 \%$ responden menyatakan informan belum atau tidak pernah menulis karya ilmiah.

Ketiga, faktor-faktor yang menghambat partisipasi guru dalam menulis karya ilmiah adalah keterbatasan waktu, motivasi, kurangnya pengetahuan tentang kompetensi 
profesional, keterbatasan mengembangkan ide.

\section{DAFTAR PUSTAKA}

(1) Ariffianto, Mahar dan Corry Liana. (2015). Profesionalisme Guru SMA di Lamongan pada Masa Orde Baru Pelita $V$ \& VI (Tahun 1989 sampai 1998). Jurnal Pendidikan Sejarah, Vol. 3 Nomor 3, hal. 396.

(2) Astuti, D. (2009). Desentralisasi dan Partisipasi dalam Pendidikan. UNY, Yogyakarta.

(3) Daryanto. (2008). Evaluasi Pendidikan. Rineka Cipta, Jakarta.

(4) Fajri dan R. A. Senja. (2008). Kamus Lengkap Bahasa Indonesia. Edisi Revisi. Cet. 3. Difa Publishers, Semarang.

(5) Marijan. (2011). Cara Gampang Pengembangan Profesi Guru. Sabda Media, Yogyakarta.

(6) Peraturan Menteri Pendidikan Nasional Nomor 16 Tahun 2007 tentang Standar Kualifikasi Akademik dan Kompetensi Guru.

(7) Peraturan Menteri Negara Pendayagunaan Apratur Negera dan Reformasi Birokrasi (Permen PANRB) Nomor 16 Tahun 2009 tentang Jabatan Fungsional Guru dan Angka Kreditnya.

(8) Saroni, M. (2012). Mengelola Jurnal Pendidikan Sekolah. Ar Ruzz Media, Yogyakarta.
(9) Sudjana, N. (2016). Penilaian Hasil Proses Belajar Mengajar. Rosdikarya, Bandung.

(10) Sumardjoko, B. (2017). Pemetaan Kemampuan Guru dalam Penulisan Karya Ilmiah. The 5th Urecol Proceeding, UAD, Yogyakarta.

(11) Undang-Undang Republik Indonesia Nomor 14 Tahun 2005 tentang Guru dan Dosen. 